\title{
Duke Leopold of Lorraine, Small State Diplomacy, and the Stuart Court in Exile, |716-1729
}

\author{
Stephen Griffin
}

Department of History, University of Limerick, Limerick City, Ireland Email: Stephen.Griffin@ul.ie

\begin{abstract}
This article examines how rulers of early modern small states attempted to survive and increase their status in the ever-shifting political world of early eighteenth-century Europe. To do so it takes the example of Duke Leopold of Lorraine and his connections with the exiled James Francis Edward Stuart and his court. Like many other small state princes, Leopold was politically dependent upon the decisions of his larger neighbours and his policies were designed to ensure his continued survival and to increase his own prestige. Historians have long acknowledged the relationship between Leopold and James in 1713-15 but they have done little to explore their interactions between 1716 and 1729. In drawing attention to this neglected sequence of encounters, the article highlights their connection to broader and more well-known political affairs in the 1710s and 1720s. It demonstrates how Leopold utilized his connection with the Stuarts as he reacted to a changing political situation in Europe in the years following the Peace of Utrecht. In return, the Stuarts, seeking to achieve their political goals, could rely upon ducal advice and aid. This dynamic suggests that these small but well-connected princes and their diplomatic activities require further consideration when examining international relations.
\end{abstract}

On 9 March 1713, Duke Leopold of Lorraine and Bar (1679-1729) welcomed James Francis Edward Stuart (1688-1766) as his guest to the town of Bar-le-Duc. ${ }^{1}$ James became the newest resident in the duke's lands and his court was installed in the chateau above the town. This meeting was the result of an accord between Leopold, Louis XIV of France, and Queen Anne of Britain and Ireland, James's sister. It symbolizes the extent to which small state rulers

\footnotetext{
${ }^{1}$ Journal de Verdun, Apr. 1713, in M. J. A. Schmit, 'Petite gazette de Lorraine du règne de Léopold, extraite des journaux du temps’ (Nancy, 1873) (Bibliothèque Municipale de Nancy, 829 (555) MSS p. 308).

(C) The Author(s), 2022. Published by Cambridge University Press. This is an Open Access article, distributed under the terms of the Creative Commons Attribution licence (http://creativecommons.org/licenses/by/4.0/), which permits unrestricted re-use, distribution and reproduction, provided the original article is properly cited.
} 
and political exiles were reliant upon a decision-making process in which they had very little choice or input. Developments in international relations transpired due to the actions of the great powers. Yet, as Daniela Frigo notes, small states could 'play a political role of much greater weight' than their resources allowed. Their princes attempted to influence the choices of more powerful sovereigns and to exploit international conflicts for their own gain. ${ }^{2}$ In this way, it is important to note that these lesser powers and their activities must be taken into account when considering wider developments in international politics. Such endeavours, in and of themselves, can offer fresh insights and perspectives to well-known (and often extensively examined) political connections and relationships.

Nowhere is this small state dynamic better illustrated than in the composite state of Lorraine and Bar where the geographic position of both duchies, situated between both France and the Holy Roman Empire, ensured that Leopold was required to maintain a balance in his relations with both Vienna and Versailles. ${ }^{3}$ Bar was divided between the Barrois non-mouvant, under the duke's control, and the Barrois mouvant, under the jurisdiction of the Parlement de Paris. Therefore, Leopold had been required to pay homage to Louis XIV for the duchy of Bar in $1699 .{ }^{4}$ At the same time, both Lorraine and the Barrois non-mouvant were ostensibly a part of the Holy Roman Empire. Further complicating ducal authority were the bishoprics of Metz, Toul, and Verdun, which, although geographically situated within Leopold's state, were under French jurisdiction. Due to the duchy's strategic importance, the French invaded on two occasions between 1633 and 1660 and 1670 and 1697, driving the House of Lorraine into exile. ${ }^{5}$ Exile was, and continues to be, a key dynamic of the past and present as people are expelled or flee their homelands for religious and/or political reasons. ${ }^{6}$ Philip Mansel and Thorsten Riotte have noted that royal exile has been an occurrence in almost every state in Europe. ${ }^{7}$ Duke Leopold was born

\footnotetext{
${ }^{2}$ Daniela Frigo, ed., Politics and diplomacy in early modern Italy: the structure of diplomatic practice, 1450-1800, trans. Adrian Belton (Cambridge, 2000), p. 4; David Parrot, 'A "prince souverain" and the French crown: Charles de Nevers, 1580-1637', and Derek McKay, 'Small-power diplomacy in the age of Louis XIV: the foreign policy of the Great Elector during the 1660s and 1670s', in Robert Oresko, G. C. Gibbs and H. M. Scott, eds., Royal and republican sovereignty in early modern Europe: essays in memory of Ragnhild Hatton (Cambridge, 1997), pp. 149-87, 188-215.

${ }^{3}$ Renate Zedinger, 'Entre Vienne et Versailles: un enjeu politique difficile pour Léopold de Lorraine', in Anne Motta, ed., Échanges, passages et transferts à la cour du duc Léopold, 1698-1729 (Rennes, 2017), pp. 93-104.

${ }^{4}$ Louis de Rouvroy, duc de Saint-Simon, Mémoires de Saint-Simon, ed. A. de Boislisle (43 vols., Paris, 1888), VI, pp. 391-5.

${ }^{5}$ See Laurent Jalabert, Charles V de Lorraine (1643-1690) ou la quête de l'état (Metz, 2017); Phil McCluskey, Absolute monarchy on the frontiers: Louis XIV's occupation of Lorraine and Savoy (Manchester, 2013); Marie-Catherine Vignal Soleyreau, Le cardinal de Richelieu à la conquête de Lorraine: correspondence, 1633 (Paris, 2010).

${ }^{6}$ Nicholas Terpstra, Religious refugees in the early modern world: an alternative history of the Reformation (Cambridge, 2015); also see Benjamin J. Kaplan, Divided by faith: religious conflict and the practice of toleration in early modern Europe (Cambridge, MA, 2007), pp. 158-60.

${ }^{7}$ Philip Mansel and Torsten Riotte, eds., Monarchy and exile: the politics of legitimacy from Marie de Médicis to Wilhelm II (Basingstoke, 2011), p. 2.
} 
in exile, the son of Duke Charles V and Eleonore Maria of Austria, the half-sister of Emperor Leopold I. He had been raised in the Hofburg at Innsbruck and spent much time in Vienna before serving with the Imperial army in Hungary and the Rhineland. ${ }^{8} \mathrm{He}$ was not restored until the signing of the Treaty of Ryswick in 1697.

Exiles may have viewed their situation as only temporary and they could seek aid to realize their hopes of returning home. ${ }^{9}$ Indeed, expulsion and forced migration could be used by the persecuted to encourage military intervention on their behalf and to promote confessional alliances. Small state princes and governments harboured and aided exiles and refugees for a variety of reasons, and these often served their own interests. ${ }^{10}$ In 1685, Frederick Wilhelm, elector of Brandenburg, invited Huguenots to settle in his lands that had been depopulated in the Thirty Years' War. Leopold of Lorraine encouraged Irish Jacobites to repopulate his lands post-1698. Alternatively, princes may have offered only token support such as that which the princes of the Holy Roman Empire offered Charles II in exile in the 1650s. ${ }^{11}$

Amongst larger states, the rivalry between France and the Habsburg emperors in the seventeenth and eighteenth centuries saw both protagonists support royal exiles in their struggle for dominance. The Habsburgs supported the House of Lorraine in attempting to reclaim its duchy that the French had occupied. Louis XIV played host to the exiled Francis Rákóczi II following the Habsburg defeat of the Hungarian rebellion in 1711. Louis also supported the exiled Stuarts in their attempts to regain the thrones of Britain and Ireland. ${ }^{12}$ Residing in France since 1688, James Francis Edward had been recognized by Louis as James III of England and Ireland and VIII of Scotland in September 1701. In a bid to be restored, the Stuarts would find themselves

\footnotetext{
${ }^{8}$ Guy Cabourdin, Histoire de la Lorraine: les temps modernes: de la Paix de Westphalie à la fin de l'ancien régime (Nancy, 1990), p. 69; Alain Petiot, 'La minorité du duc Léopold à Innsbruck', in Renate Zedinger, ed., Innsbruck 1765: Prunkvolle Hochzeit, fröhliche Feste, tragischer Ausklang (Bochum, 2015), pp. 85-107; Renate Zedinger, Franz Stephan von Lothringen (1708-1765): Monarch, Manager, Mäzen (Vienna, 2008), p. 23.

${ }^{9}$ Owen Stanwood, 'Between Eden and empire: Huguenot refugees and the promise of new worlds', American Historical Review, 118 (2013), p. 1324.

${ }^{10}$ Geert Janssen, The Dutch revolt and Catholic exile in Reformation Europe (Cambridge, 2014), pp. 183-4; idem, 'The legacy of exile and the rise of humanitarianism', in Brian Cummings, Ceri Law, Karis Riley, and Alexandra Walsham, eds., Remembering the Reformation (Abingdon, 2020), pp. 236-7; Susanne Lachenicht, 'Refugees and refugee protection in the early modern period', Journal of Refugee Studies, 30 (2017), pp. 265-70.

${ }^{11}$ François David, 'Les colonies des réfugiés protestants français en Brandbourg-Prusse (16851809): institutions, géographie et évolution de leur peuplement', Bulletin de la Société de l'Histoire du Protestanisme Français (1903-2015), 140 (1994), pp. 111-42; Frédéric Richard-Maupillier, 'The Irish in the regiments of Duke Leopold of Lorraine, 1698-1729', Archivium Hibernicum, 67 (2014), pp. 285-312; Ronald Hutton, Charles the Second, king of England, Scotland and Ireland (Oxford, 1989), pp. 84-5, 89, 102; Eva Scott, The travels of the king: Charles II in Germany and Flanders, 1654-1660 (London, 1907), p. 17.

${ }^{12}$ Ferenc Toth, 'Emigré or exile? Francis II Rákóczi and his exile in France and Turkey', in Mansel and Riotte, eds., Monarchy and exile, pp. 94-6; Edward Gregg, 'France, Rome and the exiled Stuarts, 1689-1713', in Edward Corp, A court in exile: the Stuarts in France (Cambridge, 2004), pp. 11-75.
} 
engaged in political intrigue with France, Sweden, Spain, and Russia in the years between 1688 and 1745. James became involved with Leopold of Lorraine as the latter sought to improve his own standing on the international stage.

Like many other small state rulers, Leopold's policies were motivated by a need to both increase the prestige of his house throughout Europe by obtaining royal status and to expand his territories. ${ }^{13}$ The duke was firmly attached to the Habsburg court, but he married the niece of Louis XIV, Elisabeth Charlotte d'Orleans, to improve relations with Versailles in 1698. He had obtained the recognition of Altesse Royale from the emperor in 1703 but he had yet to receive the honour of that title from the French crown. ${ }^{14}$ Achieving such an appellative was an act pursued by other contemporaneous houses, particularly those of Brandenburg, Medici, Hanover, Holstein, and Savoy. ${ }^{15}$ The latter half of Leopold's reign (1716-29) saw the continuation of this policy albeit with the added aim of securing the futures of Leopold's children through marriage. ${ }^{16}$

The Stuart court's stay in Lorraine has been described by many historians since the eighteenth century. Studies of Leopold's rule have frequently discussed the residency of James in Bar. Henri Baumont discusses James's arrival in 1713 and describes his departure in early $1716 .{ }^{17}$ Articles by Fourier de Bacourt and Louis Daville provide accounts of James's life in the duchy but cover much of the same ground as Baumont. ${ }^{18}$ These examinations of Leopold's interactions with James do not go beyond James's departure from the duchy. More recent examinations of Leopold's rule have been just as

${ }^{13}$ See Henri Baumont, Études sur le règne de Léopold duc de Lorraine et de Bar (1697-1729) (Paris, 1894), pp. 614-18; Cabourdin, Histoire de la Lorraine, pp. 128-9; Jérémy Filet, 'Jacobitism on the Grand Tour? The duchy of Lorraine and the 1715 Jacobite rebellion in the writings of displacement (1697-1736)' (Ph.D. thesis, Manchester Metropolitan University and Université de Lorraine, 2021); Phil McCluskey, 'Louis XIV, Duke Leopold I and the neutrality of Lorraine, 1702-1714', European History Quarterly, 45 (2015), pp. 37-8; Charles Lipp, Noble strategies in an early modern small state: the Mahuet of Lorraine (Rochester, 2011), pp. 118-19; Jonathan Spangler, 'Transferring affections: princes, favourites and the peripatetic houses of Lorraine and Beauvau as trans-regional families', in Michael Gehler and Wolfgang Mueller, eds., International history in theory and practice (Vienna, 2017), p. 642; Zedinger, 'Entre Vienne et Versailles', p. 99.

${ }^{14}$ That closeness to the emperor ensured that the French never wholly trusted him and maintained an envoy extraordinaire in Lorraine to monitor his activities. Simultaneously, during the War of the Spanish Succession, members of the court in Vienna accused Leopold of being partisan to the French. Laurent Jalabert, 'Monsieur d'Auddifret, résident et observateur à la cour de Lorraine (1702-1733)', in Motta, ed., Échanges, passages et transferts, pp. 139-50; McCluskey, 'The neutrality of Lorraine, 1702-1714', p. 45; Zedinger, 'Entre Vienne et Versailles', p. 101.

${ }^{15}$ Robert Oresko, 'The House of Savoy in search for a royal crown in the seventeenth century', in Oresko, Gibbs, and Scott, eds., Royal and republican sovereignty, pp. 347-8.

${ }^{16}$ E. William Monter, A bewitched duchy: Lorraine and its dukes, 1477-1736 (Geneva, 2009), p. 153.

${ }^{17}$ Baumont, Léopold duc de Lorraine, pp. 234-7, 285-7.

${ }^{18}$ Fourier de Bacourt, 'Le Chevalier de Saint-Georges (Jacques III Stuart) à Bar-le-Duc, 17131716', Mémoires de la Société des Lettres, Sciences et Arts de Bar-le-Duc, 7 (1909), pp. 225-46; Louis Daville, 'La séjour du Prétendant Jacques-Edouard Stuart à Bar-le-Duc (1713-1716)', Le Pays lorrain (1928), pp. 337-49. A more recent study utilizing largely unexamined sources from Nancy is Jérémy Filet, 'Jacobitism in an early-modern state: the duchy of Lorraine and the 1715 rebellion' (MA thesis, Université de Lorraine, 2016), pp. 48-74. 
cursory in their approach to James. That James was harboured by Leopold because of the negotiations at Utrecht is fleetingly mentioned by Guy Cabourdin, Robert Parisot, and Frédéric Richard-Maupillier. ${ }^{19}$

Accounts of Leopold are even more infrequent in Jacobite studies. G. H. Jones did not examine the period in Lorraine in any great detail and neither did Bruce Lenman. ${ }^{20}$ Leopold receives minor but notable mentions by Daniel Szechi who alludes to the duke's involvement in the 1715 rebellion and his reasons for refusing to harbour James post- $1715 .^{21}$ The best English-language study of James's residency in Leopold's state remains Edward Corp's chapter on the subject in his examination of the Stuarts in France. ${ }^{22}$ Yet Corp's work does not consider Lorraine after the Stuart court departed. Older scholarship was somewhat more attentive to the Lorraine-Stuart connection post-1716. Under the nom de plume of Martin Haile, Mary Halle's biography of James provides some references to Leopold's continued contact with the Stuart court after $1716 .^{23}$ Yet 'Haile' provided only a brief discussion of this subject, noting the latter's continued involvement in Jacobite intrigue until 1716. In examining this treatment of Leopold and James, one may be forgiven for thinking that contact between both effectively ended in 1716. One source even suggests that the two princes parted on bad terms, stating that Leopold's court was outraged by James's activities in late $171 .^{24}$

The purpose of this article is to reconstruct the relationship between Leopold and the Stuart court following James's departure from Lorraine in 1716 and to outline his efforts in supporting James in the second half of his reign. To do so, it frames their interactions within the duke's wider foreign policy and highlights how Lorraine-Stuart relations fluctuated due to continuously changing developments and alliances among the great powers. The relationship will be examined over three stages, each revealing a series of increasingly underexplored encounters linked to these wider international relations. The first section outlines Leopold's initial reasons for supporting James, their relationship during James's time in Lorraine and Leopold's role in aiding his guest. The second section discusses Leopold's continued contact with the Stuart court after 1716, and his subtler involvement in its affairs due to his own political position and a wider European situation. Leopold's

\footnotetext{
${ }^{19}$ Cabourdin, Histoire de la Lorraine, pp. 126-7; Robert Parisot, Histoire de Lorraine (duché de Lorraine, duché de Bar, Trois-Évêchés): Tome II de 1552 à 1789 (2nd edn, Brussels, 1978), p. 111; Frédéric Richard-Maupillier, 'Les Irlandais à la cour du duc Léopold de Lorraine (1698-1729)', in Motta, ed., Échanges, passages et transferts, pp. 56-7.

${ }^{20} \mathrm{G}$. H. Jones, The main stream of Jacobitism (Cambridge, MA, 1954), pp. 90, 107, 114; Bruce Lenman, The Jacobite risings in Britain, 1689-1746 (London, 1980), p. 109.

${ }^{21}$ Daniel Szechi, 1715: the great Jacobite rebellion (New Haven, CT, and London, 2006), p. 84; idem, The Jacobites: Britain and Europe, 1688-1788 (Manchester, 2019), p. 145.

${ }^{22}$ Corp, A court in exile, pp. 260-99; also see the individual chapter on Lorraine in idem, Sir David Nairne: the life of a Scottish Jacobite at the court of the exiled Stuarts (Witney, 2017); and Filet, 'Jacobitism on the Grand Tour?', pp. 82-124.

${ }^{23}$ Martin Haile, James Francis Edward: the old chevalier (London, 1907).

${ }^{24}$ François Jean Baptiste Nöel, Mémoires pour servir l'histoire de Lorraine (7 vols., Nancy, 1840), V, p. 101.
} 
contact with James was limited in the early to mid-1720s but as the final section of this article highlights, the duke still had a part to play in James's affairs as both a protagonist attempting to be involved in grander events of state and as a monarch under pressure from his larger neighbours.

Throughout the War of the Spanish Succession, Leopold had maintained neutrality despite the French once again occupying the duchy. He also attempted to mediate between Louis XIV and the emperor and his allies in a bid to advance his own ambitions. ${ }^{25}$ However, he had been disappointed in his failure to obtain the duchies of Mantua and Monferrato and the principality of Arches-Charleville in $1708{ }^{26} \mathrm{He}$ still sought indemnities for those territorial losses and acknowledgement of the Treaty of Ryswick by which France would be obliged to withdraw from his lands.

In 1712, an opportunity arose for the duke to promote his interests. The previous year, in October 1711, the Tory administration in Britain, led by Robert Harley, earl of Oxford, had signed preliminaries with France for a congress at Utrecht. One of the issues that needed to be resolved was James's residency. As a settlement would not be reached while Louis XIV continued to provide protection to the Stuarts, James's removal would allow negotiations to continue between Britain and France. Louis, who could no longer afford to keep James as his guest, conceded to this. ${ }^{27}$ Oxford initially suggested that James might be moved to Rome before suggesting Lorraine as an alternative. However, additional suggestions came from Henry St John, Viscount Bolingbroke, Oxford's rival for the leadership of the ministry. Bolingbroke, who was jealous of Oxford's position within the party and his closeness to Queen Anne, proposed Rome, the Holy Roman Empire, and Spain as potential residencies for James's court. The French dismissed all options except for Lorraine and suggested that James be sent to Bar-le-Duc. ${ }^{28}$ Once the Tories agreed, Louis secured the consent of Leopold in August and September 1712. ${ }^{29}$

\footnotetext{
${ }^{25}$ McCluskey, 'The neutrality of Lorraine, 1702-1714', pp. 42, 49.

${ }^{26}$ As heir presumptive to Duke Ferdinando-Carlo Gonzaga, Leopold's efforts to secure this inheritance came to naught following an Imperial ban which decried Ferdinando-Carlo a traitor and saw the emperor confiscate Mantua and Monferrato in 1708. The emperor claimed Mantua for himself and granted Monferrato to the duke of Savoy. As for Arches-Charleville, Louis XIV remained adamant that the decision of that inheritance be made by the Parlement de Paris which awarded the principality to the princess of Condé after which it was annexed to France. Charles W. Ingrao, In quest and crisis: Emperor Joseph I and the Habsburg monarchy (West Lafayette, IN, 1979), p. 120.

${ }^{27}$ Gregg, 'France, Rome and the exiled Stuarts', p. 73; John A. Lynn, The wars of Louis XIV, 1667-1714 (London, 1999), pp. 325, 336; Daniel Szechi, Jacobitism and Tory politics, 1710-1714 (Edinburgh, 1984), pp. 184-5.

${ }^{28}$ Gregg, 'France, Rome and the exiled Stuarts', pp. 71-2. For Oxford and Bolingbroke, see W. A. Speck, 'Robert Harley, first earl of Mortimer and Oxford'; and H. T. Dickinson, 'Henry St John, styled First Viscount Bolingbroke', in ODNB.

${ }^{29}$ Louis to D'Auddifret, 25 Aug. 1712, in Baumont, Léopold duc de Lorraine, p. 234 n. 2; D'Auddifret to Louis, 6 Sept. 1712 (Archives des affaires étrangères (AAE), CP Lorraine, 83, fos. 13-14).
} 
James enjoyed good relations with Leopold. He was a guest at the ducal court in Lunéville on at least five occasions where he exchanged snuff boxes with the duchess and hunted with the duke. ${ }^{30}$ The festivities held in James's honour were lavish and expensive. During James's first three-week visit, one feast and fireworks display alone cost 15,000 livres. ${ }^{31}$ To act as his intermediary with James, Leopold utilized one of his chamberlains, Owen O'Rourke. ${ }^{32}$ An Irish Jacobite exile, O'Rourke had a history of service to the Stuarts. He had fought for James II in the Williamite War in Ireland (1689-91) and had then served with the Stuart army in France between 1691 and 1697. Commissioned as a captain in Leopold's ducal guards in 1697, the duke entrusted him with minor diplomatic missions in 1707 and rewarded him with an appointment as chamberlain. O'Rourke acted as a link between James in Bar and Leopold at Lunéville. The duke appointed him a counsellor of state in 1715. However, O'Rourke would become increasingly attached to James in the years that followed. ${ }^{33}$

Leopold was a former exile and was sympathetic to James's plight, yet he was spurred on by his own ambitions. ${ }^{34}$ While the Stuart court was in Bar-le-Duc, Leopold's envoy in London was informing him of support within the Tory ministry for James. With the Protestant electoral family of Hanover expected to succeed Queen Anne, reports informed Leopold that the public was dissatisfied with the Hanoverians, and that their succession would not be peaceful. ${ }^{35}$ By allowing James's settlement in Bar, Leopold had continued his policy of maintaining good relations with Louis while seeking favourable support from the allies negotiating at Utrecht. ${ }^{36}$ At the same time, Leopold would do much for James in terms of international politics. He had been persuaded to allow James's Anglican subjects to have religious services in Bar, an important move that highlighted James's religious tolerance and countered propaganda that sought to paint the Stuart court as anti-Protestant. ${ }^{37}$ In Britain, the Whig Opposition sought to keep James as far away from Britain as possible. They succeeded in passing a motion in the House of Lords which forced the government to make a formal demand that Leopold expel James in 1713. In this instance, Leopold had refused to comply, but James was already being urged by both Oxford and Bolingbroke to leave

\footnotetext{
${ }^{30}$ Filet, 'Jacobitism in an early-modern state', p. 60; Haile, James Francis Edward, p. 141.

${ }^{31}$ De Bacourt, 'Le Chevalier de Saint-Georges', pp. 228-9.

${ }^{32}$ D'Auddifret to Louis XIV, 13 Sept. 1712 (AAE, CP Lorraine, 83, fos. 27-8).

${ }^{33}$ A short biography of O'Rourke can be found in Alain Petiot, Les Lorrains et les Habsbourg: dictionnaire biographique illustré des familles Lorraines au service de la maison d'Autriche (2 vols., Aix en Provence, 2014), II, pp. 500-1. For a more substantial overview, see Stephen Griffin, 'Princes, agents and friends: Count Owen O'Rourke and the Stuart presence in Vienna, 1727-1743' (Ph.D. thesis, University of Limerick, 2020).

${ }^{34}$ Concerning James, he purportedly remarked: 'Monsieur, vous oubliez que ce prince est malheureux et qu'il était roi' and 'Il m'a rendu justice: il a pensé que je n'ai fait que mon devoir en secourant un malheureux.' See Nöel, Mémoires, V, p. 101.

${ }^{35}$ Filet, 'Jacobitism in an early-modern state, pp. 51-2, 52 n. 287.

${ }^{36}$ McCluskey, 'The neutrality of Lorraine, 1702-1714', p. 49; Cabourdin, Histoire de la Lorraine, p. 127.

${ }^{37}$ Filet, 'Jacobitism in an early-modern state', p. 58.
} 
Lorraine. This stemmed from both men attempting to win favour with the Hanoverians. ${ }^{38}$

If Leopold was optimistic about James being restored, he sought to further his influence with the exiled court. This led him to act as intermediary in seeking a Habsburg bride for James in 1713-14. He attempted to establish a match between James and the emperor's youngest niece, Archduchess Maria Amalia. If the match could be made, it would have been both a prestigious and honourable action from which he could further his own reputation. It would have increased his influence in both London and Vienna, and both the Stuarts and the Habsburgs would have been indebted to Leopold for setting up the match. ${ }^{39}$ The duke's envoy in Vienna reported that the Austrians were indifferent to James's interests and believed him to be too closely attached to France. A prospective union would only be likely if James was on the throne. ${ }^{40}$

Leopold still harboured plans to negotiate a strategic marriage with the emperor but without James. He envisaged uniting the House of Lorraine with the House of Habsburg and Emperor Charles VI was the sole surviving male following the deaths of his father and brother, Emperors Leopold and Joseph in 1705 and 1711 respectively. In 1715, Leopold had hoped to establish negotiations with Vienna for a marriage between his brother François and a Habsburg archduchess. ${ }^{41}$ The death of François from smallpox in July 1715 ended this endeavour but as shall be seen, the duke would once again broach the possibility of a Habsburg-Lorraine union as his children grew older.

\section{II}

James's claims to the British and Irish thrones were ignored upon the death of Anne in August 1714. Instead, George Ludwig of Hanover was proclaimed George I of Britain and Ireland. The Hanoverian succession was followed by a Jacobite rebellion in Scotland in September 1715. When word of this reached Lorraine, James quickly departed to join his supporters in October. He had already received a loan of 25,000 louis d'or from Leopold and it was no secret that the loan had been made. ${ }^{42}$ Following the rebellion's defeat, James fled Scotland and returned to Lorraine in March 1716. Leopold faced immediate

\footnotetext{
${ }^{38}$ Edward Gregg, Queen Anne (London, 1980), p. 368; Haile, James Francis Edward, pp. 143-4; Szechi, Jacobitism and Tory politics, pp. 184-91.

${ }^{39}$ Des Armoises to Leopold, 22 Feb. 1714 (Archives des Meurthe-et-Moselle (ADMM), 3F 136, fo. 22). For this type of dynastic matchmaking, see John Condren, 'The dynastic triangle in international relations: Modena, England and France, 1678-1685', International History Review, 37 (2015), pp. $700-20$.

${ }^{40}$ Des Armoises to Leopold, 28 Mar. 1713 (ADMM, 3F 136, fo. 7); Des Armoises to Leopold, 10 Feb. 1714 (ADMM, 3F 136, fo. 20).

${ }^{41}$ Baumont states that the archduchess would have been Maria Magdalena, the youngest child of Emperor Leopold I. On the contrary, Zedinger writes that it was Maria Josepha, the eldest daughter of Emperor Joseph I. Baumont, Léopold duc de Lorraine, p. 280; Zedinger, Franz Stephan, p. 31.

${ }^{42}$ Penteriedter to Charles VI, 15 Dec. 1715 (Österreichisches Staatsarchiv/Haus-, Hof-, und Staatsarchiv (ÖStA/HHStA), Frankreich 27, fo. 26); D'Auddifret to d'Orléans, 21 Oct. 1715, qu. in Baumont, Léopold duc de Lorraine, pp. 285-6; Corp, A court in exile, p. 296; Szechi, 1715, p. 163.
} 
pressure from France to refuse James's residency. ${ }^{43}$ This stemmed from a changed political situation in France. Louis XIV had died in September 1715 and was succeeded by the five-year-old Louis XV. With Louis XV still a minor, a regency was established under Louis XIV's nephew and Leopold's brother-in-law, Philippe d'Orléans. The Orléans family would gain the French crown if the infant Louis XV died. Many in France believed that Philip V of Spain, as Louis's closest living relative, was the rightful heir. Philip had been forced to renounce his claims to the French crown in the Treaty of Utrecht but claimed the renunciation was invalid. Orléans needed to maintain peace in France to secure his family's succession. Anxious to form an alliance with Britain and protect France from invasion, he demanded that James be removed from Lorraine. Following James's return to the duchy, Leopold was obliged to bow to diplomatic pressure and requested his departure. ${ }^{44}$

Although the Jacobites were defeated, Leopold continued to help James when few other monarchs were willing to do so. He now maintained a far subtler line and reduced his involvement in James's affairs. He continued to take an interest in James's search for a bride writing that: 'Nothing is more essential for the Chevalier [James]'s interest than that he should be married. ${ }^{45}$ However, the duke did not instruct his diplomats to promote a Stuart marriage as he had previously done. He permitted his courtiers to serve James in secret. In this fashion, O'Rourke entered communication with the court of Charles Philip, the Elector Palatine, regarding a potential marriage with the latter's daughter, Elisabeth Auguste. The correspondence lasted until January 1717, only ending when James and his court decided that the emperor would not tolerate the match. $^{46}$

James moved to the papal enclave of Avignon where he resided until February $1717 .{ }^{47}$ The defeat of the Jacobites in 1715 had made it clear that the Stuarts could not be successfully restored without foreign aid. An Anglo-French alliance had formed in November 1716 and while Orléans was regent there could be no question of French help. France then acceded to a Triple Alliance with Britain and the Dutch Republic in October $1717 .^{48}$ Jacobite agents were dispatched to entreat with the emperor, the king of Sweden, and the tsar of Russia. When James's initial choice of envoy to Vienna refused the commission, he next requested O'Rourke on the condition

\footnotetext{
${ }^{43}$ The emperor did not become involved. He stated that the situation was between Leopold and France. Des Armoises to Leopold, 21 Jan., 22 Mar. 1716 (ADMM, 3F 136, fos. 37, 47).

${ }^{44}$ Derek McKay and H. M. Scott, The rise of the great powers (London, 1983), pp. 65-6, 106-9; Philippe de Courcillon, marquis de Dangeau, Journal du marquis de Dangeau avec les additions du duc de Saint-Simon, XVI (Paris, 1859), p. 337.

${ }^{45}$ Memoir of the duke of Lorraine, 12 Dec. 1716, in Historical Manuscripts Commission (HMC), Calendar of the Stuart papers belonging to His Majesty the King, preserved at Windsor Castle, III (London, 1907), p. 562.

${ }^{46}$ James to Leopold, 12 Aug. 1716; O'Rourke to Mar, 29 Aug. 1716, in HMC, Stuart papers, II, pp. 339, 389-90; Mar to O’Rourke, 3 Jan. 1717, in ibid., III, p. 397.

${ }^{47}$ Corp, A court in exile, pp. 298-312.

${ }^{48}$ Mar to O'Rourke, 18 Oct. 1716; Mar to O'Rourke, 22 Oct. 1716, in HMC, Stuart papers, III, pp. 97, 122; J. H. Shennan, Philippe, duke of Orléans (London, 1979), pp. 60-1.
} 
that the duke approved. ${ }^{49}$ However, Leopold advised against it. Anglo-Austrian relations were good and he informed O'Rourke that anyone who travelled to Vienna on James's behalf would be 'bid away shamefully. ${ }^{50}$

By now, it was expected that James would leave Avignon and move to Italy. It was still believed that an alternative home could be found for the exiled court and that the emperor could be approached for support. O'Rourke was directed to discuss, with Leopold, the prospect of establishing James in Flanders with Imperial consent. Leopold did not think that the emperor would consent to this, but he was willing to forward transcriptions of the letters from Avignon to Vienna. Although he believed any direct approach to the emperor on James's part would be useless, Leopold stated that he would 'sound' out the Imperial court regarding James's situation and 'let them know the advantages they may one day reap' in supporting the Stuarts. ${ }^{51} \mathrm{He}$ suggested either Switzerland or Venice as a residency for James. ${ }^{52}$

James was open to gaining residency in Venice. However, he was bothered by the duke's proposal that he should arrive there unannounced and feared what that might do to Venetian trade with Britain. He gave the duke powers to represent him and expressed the hope that the emperor would consent to his proposed stay in Venice..$^{53}$ However, Leopold disagreed with soliciting the emperor's permission for this request. In his view, openly asking the emperor and the Venetians to assist James would achieve nothing and the stay in Venice would be refused. He advised James to travel to Venice in secret where, upon announcing his arrival, the emperor might not disapprove of his presence. Meanwhile, if James moved to Flanders, it would be seen as an open declaration by the emperor against George I. There was a belief in Avignon that the alliance between Britain, the Dutch Republic, and France would be aimed against both James and the emperor. Leopold eventually agreed to forward a letter from James to Vienna "with all the instances he could reasonably make in so nice a matter'. ${ }^{54}$

To be fair to Leopold, his own interests could not be jeopardized by overtly supporting James. He still sought compensation for the loss of Monferrato and Mantua and he had been told that there would be little chance of gaining the duchy of Luxembourg as compensation. ${ }^{55}$ The affair was not officially settled until 1722 when the emperor granted him the duchy of Teschen in Silesia. Therefore, Leopold was wary of openly supporting the Stuarts in December 1716. It might have displeased the emperor and have had negative ramifications for his attempt to gain compensation for Monferrato. When the question

\footnotetext{
49 Southcott to Mar, 1716; Mar to O'Rourke, 15 June 1716, in HMC, Stuart papers, II, pp. 188-9, 221; James to Leopold, 13 June 1716 (ADMM, 3F 208, fo. 85).

${ }^{50}$ O'Rourke to Mar, 27 June 1716, in HMC, Stuart papers, II, p. 238.

${ }^{51}$ Mar to O'Rourke, 29 Oct. 1716, O'Rourke to Mar, 12 Nov. 1716, memoir of the duke of Lorraine, 12 Dec. 1716, in ibid., III, pp. 152-3, 204-5, 561-2.

${ }^{52}$ Memoir of the duke of Lorraine, 12 Dec. 1716, in ibid., III, p. 561.

53 James to Leopold, 21 Dec. 1716 (ADMM, 3F 208, fo. 88).

${ }^{54}$ Memoir of the duke of Lorraine, 22 Dec. 1716, O’Rourke to Mar, 22 Dec. 1716, Mar to O'Rourke, 3 Jan. 1717, O'Rourke to Mar, 16 Jan. 1717, in HMC, Stuart papers, III, pp. 331-2, 393, 453-4, 577-8.

${ }^{55}$ Des Armoises to Leopold, 21 Jan. 1716 (ADMM, 3F 136, fo. 38).
} 
of James residing in Venice or in the Low Countries was broached in Vienna, the Lorraine envoy had added that Leopold would not aid James if it was disadvantageous to the emperor. The response from the Imperial ministers was that James and his father had never done anything for the House of Habsburg. The emperor would not allow the Stuart court to reside in one of his dependencies and he would not risk a political fallout with Britain and her allies. ${ }^{56}$ In addition, there were still outstanding issues to be resolved with France, and Orléans had a keen dislike for the Stuarts. ${ }^{57}$ The French were required by the Treaty of Baden to honour the articles of Ryswick and to resolve all outstanding territorial issues on the border with Lorraine. There were numerous conferences subject to lengthy delays. The terms, including French recognition of the duke's use of the prerogative Son Altesse Royale, were not agreed until the Treaty of Paris in January $1718^{58}$

While Leopold negotiated with Paris and Vienna, James moved into the palace of Urbino in Italy in July 1717 before finally establishing his court in Rome in the Palazzo del Re in November $1719 .^{59}$ The next few years would see Leopold limit his involvement with James and the Stuart court. The duke's objectives required him to tread carefully but there was still communication with James. Throughout the 1720s, James continued to write to the duke, informing him of his marriage in 1719 and the birth of his sons. ${ }^{60}$

The influence and impact that exiles and refugees wield within their host societies is both well-documented and well-known. ${ }^{61}$ In Rome, James was granted special precedence over all ambassadors and princes of the church and was allowed to nominate cardinals. In 1723, a dispute arose in Lorraine concerning the Benedictine abbey of Saint-Mihiel. The position of abbot was contested by the abbot of Lenoncourt and Fr. Benoit Belsoi of the Benedictine Congregation of Saint Vanne. Belsoi issued a summons for Lenoncourt to travel to a tribunal in Rome which the court of Lorraine ordered him to ignore. In a bid to solve the problem, Leopold dispatched an envoy to Pope Innocent XIII but also expelled the Congregation of Saint Vanne from the duchy. Leopold sought help from James who wrote that he was happy to aid his representative in dealing with the pope. He was clearly utilizing his influence in Rome to support Leopold and to repay the assistance he had previously received. An accommodation was ultimately reached after Leopold allowed the expelled monks to return. Belsoi relinquished his claim to the abbey in

\footnotetext{
${ }^{56}$ Des Armoises to Leopold, Dec. 1716 (ADMM, 3F 136, fo. 67).

${ }^{57}$ Corp, A court in exile, p. 172.

${ }^{58}$ Cabourdin, Histoire de la Lorraine, pp. 127-8; McCluskey, 'The neutrality of Lorraine, 1702-1714', pp. 46-7.

${ }^{59}$ See Edward Corp, The Jacobites at Urbino: an exiled court in transition (London, 2009).

${ }^{60}$ James to Leopold and Elisabeth Charlotte, 10 Sept. 1719 (Royal Archives (RA), Stuart papers, 16, fo. 289); James to Leopold, 1 Jan. 1721 (ADMM, 3F 208, fo. 92); James to Leopold, 1725 (RA, Stuart papers, 80 , fo. 141).

${ }^{61}$ See, for example, Jarrell C. Jackman and Carla M. Borden, eds., The muses flee Hitler: cultural transfer and adaptation, 1930-1945 (Washington, DC, 1983); and Daniel Snowman, The Hitler emigrés: the cultural impact on Britain of refugees from Nazism (London, 2003).
} 
favour of Lenoncourt, but it was agreed that he would be Lenoncourt's heir and would receive a pension from Rome. ${ }^{62}$

Despite James's aid, the duke could not be publicly associated with him. Fearful that Owen O'Rourke would pay homage to James, Leopold refused to send O'Rourke to Rome as his emissary in $1724 .{ }^{63}$ The limited communication was a wise move. In 1722, there had been a plot to restore the Stuarts by rousing Jacobite support in England. This would be reinforced by Irish officers from France and Spain who would land with arms and ammunition. The plan collapsed once the French informed London that they had received Jacobite requests for military assistance and had discovered plans for a Jacobite invasion. ${ }^{64}$

The removal of James from Lorraine had certainly helped Leopold. Since 1718, the duke had sought to join the Quadruple Alliance between Britain, France, the Dutch Republic, and the emperor in a bid to finally obtain territorial possessions in Italy. ${ }^{65}$ In 1721, George I had assured Leopold that he would support the duke's aspirations at the Congress of Cambrai.$^{66}$ George's ambassador in France had even assured London that the duke was not supporting James. Indeed, from 1715 onwards, the duke had cultivated links with members of prominent British families who supported the Hanoverians and who had passed through the duchy on the Grand Tour. ${ }^{67}$

At this point, Leopold was engaged in his most important attempt at advancing his dynasty. He had never abandoned his hopes of a marital union with Emperor Charles VI, the last surviving male Habsburg. In 1713, Charles had issued the Pragmatic Sanction which designated his children as his direct heirs ${ }^{68}$ If Charles had no male offspring, then his eldest daughter was to succeed him. Charles's only son had died in November 1716 and his eldest surviving child was the archduchess Maria Theresa, born in 1717. From 1720 until his death in 1740 , the emperor's efforts were devoted to making concessions to various monarchs to ensure their acceptance of his daughter's succession. ${ }^{69}$ In his search for a suitable spouse for his daughter, he needed to avoid a marital union that would 'absorb' the House of Habsburg. ${ }^{70}$ He would find a suitable match from the House of Lorraine. Leopold had been considering a marriage between his own eldest son, Léopold Clement, and Maria Theresa. When Léopold Clement died of smallpox in June 1723, attention quickly shifted to his younger brother, Francis Stephen, who made a good impression on the

\footnotetext{
${ }^{62}$ James to Leopold, 12 Nov. 1723 (RA, Stuart papers, 70, fos. 33-4); Augustin Calmet, Histoire de Lorraine (7 vols., Nancy, 1757), VII, pp. 348-50; Edward Corp, The Stuarts in Italy, 1719-1766: a royal court in permanent exile (London, 2011), p. 17.

63 O’Rourke to James, 8 Apr. 1724 (RA, Stuart papers, 73, fo. 98).

${ }^{64}$ See G. V. Bennett, The tory crisis in church and state, 1688-1731: the career of Francis Atterbury, bishop of Rochester (Oxford, 1975), pp. 223-52.

${ }^{65}$ Baumont, Léopold duc de Lorraine, pp. 324-5.

${ }^{66}$ Rohan Butler, Choiseul, I: Father and son, 1719-1754 (Oxford, 1980), pp. 74-5.

${ }^{67}$ Filet, 'Jacobitism on the Grand Tour?', pp. 162-74.

${ }^{68}$ Ingrao, In quest and crisis, p. 222; Derek McKay, Prince Eugene of Savoy (London, 1977), p. 149.

${ }^{69}$ Charles Ingrao, The Habsburg monarchy, 1618-1815 (3rd edn, Cambridge, 2019), p. 298; Barbara Stollberg-Rilinger, Maria-Theresia: die Kaiserin in Ihrer Zeit (Munich, 2019), p. 17.

${ }^{70}$ McKay, Prince Eugene, p. 211.
} 
emperor. ${ }^{71}$ The implication for Leopold was that the prince would be educated in Vienna and groomed for a marriage with the archduchess Maria Theresa. ${ }^{72}$ Thereafter, Francis Stephen established his court in Vienna.

Why Leopold limited his interactions with James is clear. He needed British assistance to join the Quadruple Alliance and was reliant upon the emperor's support. In April 1723, Vienna had warned that if the duke was accused of offering refuge to James it would jeopardize the good dispositions of Britain. ${ }^{73}$ In addition, the marriage between Francis Stephen and Maria Theresa could not be endangered by open support of the Stuarts. Charles VI had no love for the Stuarts. Furthermore, as he needed international recognition for the Pragmatic Sanction, any remote connection between the Habsburgs and the Jacobites through Francis Stephen's father would have endangered the emperor's hope of British acceptance of Maria Theresa and her future husband as his heirs. A close association with James would have dashed any hope of a Habsburg-Lorraine marriage. It would also deprive Leopold of much needed British and Imperial support at Cambrai and would thwart his hopes of acceding to the Quadruple Alliance.

\section{III}

Despite stepping back from the Jacobites in the late 1710 s and early 1720 s, Leopold once again involved himself in James's affairs in 1727. To understand this move it is necessary to outline what had occurred in the wider sphere of international politics in preceding years. The Dutch had not answered the duke's requests for support in joining the Quadruple Alliance, and following the death of Orléans in December 1723 the French were determined to block his solicitations in London and Madrid. ${ }^{74}$ Issues arose at Cambrai in 1724 when Leopold's representatives were informed that George would agree to Lorraine's inclusion within the alliance only when the other members had consented. ${ }^{75}$ When Leopold sent a diplomatic mission to London to seek support from George I in 1725, his representatives were met with indifference. ${ }^{76}$

Later in the same year, all of Europe reacted to the news of a sudden and unexpected alliance between the emperor and Spain. The ministers of Vienna and Madrid signed three treaties on 30 April/1 May $1725 .^{77}$ In Britain, there were fears that the articles might be favourable to James and would threaten British interests in the Indies. On 3 September, Britain, France, and Prussia acceded to the Treaty of Hanover to counter the Vienna Alliance. ${ }^{78}$ Then, in

\footnotetext{
${ }^{71}$ Zedinger, Franz Stephan, pp. 31-4; Stefan Seitschek, Die Tagebücher Kaiser Karl VI (Vienna, 2018), pp. 194-5.

${ }^{72}$ Zedinger, Franz Stephan, p. 37; Seitschek, Kaiser Karls VI, p. 195.

${ }^{73}$ Le Begue to Leopold, 8 Apr. 1723 (ADMM, 3F 212, fo. 166).

${ }^{74}$ Baumont, Léopold duc de Lorraine, pp. 324-5, 351-2.

75 'Memorandum', 2 June 1724, and 'Notes for letter to Lord Whitworth', 7 June 1724, in HMC, Report on the manuscripts of the Right Honourable Lord Polwarth, IV (London, 1940), pp. 95, 97.

${ }^{76}$ Butler, Choiseul, pp. 79-81.

77 Tratado de paz, ajustado entre esta corona, y el emperador de Alemania (Madrid, 1725).

${ }^{78}$ Ragnhild Hatton, George I: elector and king (London, 1978), pp. 271, 276.
} 
November, two further treaties were signed by the emperor and Spain. These only served to heighten tensions in Europe and it seemed that a war was imminent. At the opening of parliament on 17 January 1727, George I accused the emperor and his Spanish allies of supporting James and of plotting to invade Britain. ${ }^{79}$ George's speech sparked a reproach from the emperor. This was seen as an affront to the king's honour and caused outrage in Britain. ${ }^{80}$ In the immediate aftermath, the emperor's envoy was forced to leave Britain and the British envoy was told to leave Vienna.

Leopold's relationship with Britain had cooled following George I's indifferent reception of his envoys in 1725. Furthermore, the duke had seen his eldest daughter dismissed as a potential bride for Louis XV. Additional estrangement was caused when the French plenipotentiary to Lorraine reported being slighted at Lunéville. ${ }^{81}$ However, the accession of Cardinal Fleury to the position of premier ministre of Louis XV had done much to reconcile Leopold's court with France. In early 1727, Leopold informed Louis XV that he would maintain neutrality in the event of war. Louis responded with approval and stated that he would respect that stance if French soldiers marched through or were garrisoned in Lorraine. ${ }^{82}$

The duke still wanted to involve himself in the affairs of the great powers. While he was informing France of his planned neutrality, he was also considering his next steps in relation to the allies of Vienna. In January 1727, James was informed by Leopold (via O'Rourke) that the emperor held George I in such contempt that once a war commenced there were plans to strip George of his dominions and to grant his electorate to his relatives, the House of Brunswick-Wolfenbüttel. ${ }^{83}$ The duke believed that the emperor and Spain would support James and had asked whether the Jacobites in Britain could be encouraged to act in a conflict. This would provide a negotiating tool with the allies of Vienna. ${ }^{84}$ The following month, Spanish forces laid siege to Gibraltar and Imperial forces were massing in Luxembourg. ${ }^{85}$ The suggestion was clear. Any forthcoming war would, in Leopold's view, see the emperor and Spain attempt to restore James.

Shortly thereafter, James wrote to Leopold requesting that O'Rourke be permitted to enter his service and travel to Vienna. Leopold consented but his

\footnotetext{
${ }^{79}$ The King's Speech at Opening the Fifth Session, 17 Jan. 1727, in Richard Chandler, ed., The history and proceedings of the House of Commons...volume 6 (London, 1742), p. 373.

${ }^{80}$ Charlotte Backerra, Wien und London, 1727-1735: Internationale Beziehungen im frühen 18. Jahrhundert (Göttingen, 2018), p. 53; Jeremy Black, “When "natural allies” fall out: Anglo-Austrian relations, 1725-1740', Mitteilungen des Österreichischen Staatsarchivs, 36 (1983), p. 135. For the reply, see Sinzendorf to Palm, 20 Feb. 1727, in Richard Chandler, ed., The history and proceedings of the House of Commons...volume 8 (London, 1742), p. 362.

${ }^{81}$ Butler, Choiseul, p. 92; Baumont, Léopold duc de Lorraine, pp. 352-7; Pierre Boye, 'Le duc d'Orléans à Lunéville, juillet-août 1725', Le Pays lorrain (1971), pp. 9-13.

${ }^{82}$ Louis XV to Leopold, 12 Feb. 1727 (AAE, CP Lorraine, 117, 60, fo. 22).

${ }^{83}$ O'Rourke to James, 15 Jan. 1727 (RA, Stuart papers, 101, fo. 120).

${ }^{84}$ Ibid.

${ }^{85}$ Michael Hochedlinger, Austria's wars of emergence: war, state and society, 1685-1797 (London, 2003), p. 200.
} 
approval was to remain a secret. There was still the potential marriage between Francis Stephen and Maria Theresa to keep in mind. What troubled him was the worrying possibility of a rival marriage candidate being put forward for Maria Theresa's hand. In the treaties signed with Spain in 1725 it had been agreed that upon Charles's death, Maria Theresa would marry the eldest son of Elisabeth Farnese, queen of Spain. This agreement has been seen as fanciful, but it weighed heavily on the mind of the duke nonetheless. ${ }^{86}$

If O'Rourke openly announced his plan to leave Lorraine and to serve James, then Leopold would be forced to inform both Vienna and Versailles and to possibly arrest him to prevent his leaving. ${ }^{87}$ Therefore, Leopold instructed him to depart Lorraine and to travel ostensibly for Italy. Upon crossing the Rhine and reaching Augsburg, he was to inform Leopold that James had asked him to enter his service. O'Rourke was to state that his attachment to the Stuarts would not allow him to compromise, and that he was accepting James's commission. ${ }^{88}$ Publicly, Leopold would disown O'Rourke. In private, O'Rourke was informed that he was still a servant of the duke - 'equally' in the service of both James and Leopold. Whether Leopold planned to utilize him further is unknown, but this measure seems to have been taken so that O'Rourke could continue to receive his pension from the court of Lorraine. This would be a welcome source of finance during O'Rourke's stay in Vienna. ${ }^{89}$

Attempting to deduce Leopold's exact motivations in this affair are difficult. However, one can make an educated supposition. Tensions between the allies of both Hanover and Vienna were evidently very high. The rift between the emperor and George I itself had been burgeoning for years due to issues in northern Germany. ${ }^{90}$ It is possible that Leopold honestly believed James had a chance of being restored with Imperial and Spanish support. It is possible that he believed himself suited to act as an intermediary between James and the emperor. If a war commenced and proved successful for the allies of Vienna, the duke might have had designs to accede to the prospective alliance between the emperor, Spain, and James. He already viewed the Alliance of Vienna as a reproduction of the Quadruple Alliance. ${ }^{91}$ Unlike George I, who had dismissed Leopold's attempt to join the Quadruple Alliance in 1725, James would have been more approachable and accommodating. A restored James would be obliged to the duke for all the support he had received since 1712 and would be more supportive of Leopold's ambitious designs.

O'Rourke left Lorraine in April 1727. Leopold notified both Versailles and Vienna that O'Rourke was gone and that he had been unable to refuse him

\footnotetext{
${ }^{86}$ Butler, Choiseul, pp. 83-4; McKay, Prince Eugene, p. 211; Stollberg-Rilinger, Maria-Theresia, p. 30.

${ }^{87}$ Craon to O'Rourke, 31 Mar. 1727 (RA, Stuart papers, 105, fo. 90).

${ }^{88}$ Ibid.

${ }^{89}$ Ibid.; O'Rourke to James, 3 Mar. 1736 (ÖStA/HHStA, England Varia 8, O'Rourke to Jakob III, fo. $364 b)$.

${ }^{90}$ Hatton, George I, p. 243; Michael Hughes, Law and politics in eighteenth-century Germany (Woodbridge, 1988), pp. 184-5; McKay, Prince Eugene, pp. 178-9; Joachim Whaley, Germany and the Holy Roman Empire, II: From the peace of Westphalia to the dissolution of the empire, 1648-1806 (Oxford, 2012), p. 141.

${ }^{91}$ Butler, Choiseul, p. 84.
} 
permission. ${ }^{92}$ When O'Rourke arrived in Vienna the Imperial court was immediately informed. The emperor then ruled that O'Rourke should be seen 'once' and then as little as possible thereafter. ${ }^{93}$ If the duke had hoped the allies of Vienna would support James he was mistaken. Spain and Britain briefly fought over Gibraltar but the emperor did not commit himself to hostilities. Peace preliminaries were signed between Britain and the emperor in May 1727 and plans were in place for a peace congress between Britain and Spain to be held at Soissons. ${ }^{94}$ Help for James would only be forthcoming in the event of war between the emperor and Britain. ${ }^{95}$ Leopold's involvement went unnoticed, and O'Rourke's presence did not affect Francis Stephen's marriage prospects.

The last major interaction between James and Leopold came a few months afterward. George I died in Hanover on 11 June 1727. In the hope of moving swiftly onward to England, James hastily departed for Lorraine with nine members of his household in July. Requests were sent to Vienna asking that he be allowed reside in the Austrian Netherlands. Leopold does not appear to have known of James's initial intentions. Once James arrived, the nature of the enterprise was disclosed, and Leopold wrote of keeping James's 'secret'. This presumably referred to James's plan and his temporary stay in the duchy. However, Leopold wrote that he would still take measures to keep himself out of trouble with France and the emperor. For the next two weeks, James stayed to the north of Nancy in Frouard and communicated with both Vienna and Paris using the cover of O'Rourke's brother-in-law and Leopold's court favourite, Marc de Beauvau-Craon. ${ }^{96}$

James's actions took France and the emperor by surprise. The Imperial ministers had been 'startled and astonished' by the news and requested that O'Rourke inform James that his plans were futile. The emperor was not annoyed with the duke. ${ }^{97}$ As James had sent a written request for residency in the Habsburg Netherlands before departing Italy, it was assumed that he was only making a temporary stop in Lorraine. This cleared Leopold of any involvement in the emperor's eyes. ${ }^{98}$ Fleury advised that James be asked to leave. ${ }^{99}$ A greater

\footnotetext{
${ }^{92}$ Leopold to Fleury, 22 Apr. 1727, Leopold to Jacquemin, 26 Apr. 1727 (ÖStA/HHStA, Lothringen Hausarchiv, 108).

${ }^{93}$ Leopold also ordered his own envoy to limit his interactions with O'Rourke. Jacquemin to Leopold, 23 May 1727 (ADMM, 3F 139, fo. 96); Jacquemin to Leopold, 23 June 1727 (ADMM, 3F 139, fo. 102); Leopold to Jacquemin, 1727 (ADMM, 3F 152, fo. 8).

${ }^{94}$ A. M. Wilson, French foreign policy during the administration of Cardinal Fleury, 1726-1743: a study in diplomacy and commercial development (London, 1936), p. 165.

${ }^{95}$ O'Rourke to James, 17 May 1727 (ÖStA/HHStA, England Varia 8, O'Rourke to Jakob III, fo. 99).

${ }^{96}$ Haile, James Francis Edward, p. 325; Corp, The Stuarts in Italy, p. 193; Graeme to O'Rourke, 4 July 1727 (RA, Stuart papers, 108, fo. 10); Jacquemin to Leopold, 14 July 1727 (ADMM, 3F 139, fo. 103); Leopold to James, 19 July 1727 (RA, Stuart papers, 108, fo. 95); Leopold to James, 21 July 1727 (RA, Stuart papers, 108, fo. 110); Leopold to James, 25 July 1727 (RA, Stuart papers, 108, fo. 132).

${ }^{97}$ O'Rourke to Graeme, 11 July 1727 (ÖStA/HHStA, England Varia 8, O'Rourke to Jakob III, fo. 124); Jacquemin to Leopold, 28 July 1727 (ADMM, 3F 139, fo. 106); Jacquemin to Leopold, 28 Aug. 1727 (ADMM, 3F 135, fo. 112).

${ }^{98}$ Jacquemin to Leopold, 28 July 1727 (ADMM, 3F 139, fo. 106).

${ }^{99}$ Butler, Choiseul, p. 93.
} 
cause for concern was the response of the British. Leopold feared that they would not forgive him for the incident and his envoy in Paris was confronted by the British ambassador. ${ }^{100}$ On 8 August, Leopold wrote to James informing him that letters from Paris and Vienna had convinced him that James could not remain in Lorraine. ${ }^{101}$ The following day, James wrote that the duke

desires me in the strongest terms to go out of his country in three days, with a plain intimation that if I delayed it longer he should be forced to oblige me to it by force...The Duke of Lorraine expresses the greatest concern to be forced to these extremities, which are certainly much against his will. But he cannot resist superior forces, neither can I. ${ }^{102}$

James returned to Italy. Leopold was notified of George II's satisfaction at his handling of the matter. ${ }^{103}$

\section{IV}

Scholarly examinations of Leopold and James have not highlighted their interactions beyond 1716. By pushing beyond this tradition and examining the relationship over a much longer period, it is clear to see that the two men did not sever ties. Both men had enjoyed a friendly relationship during James's time in Lorraine and the duke remained a useful pillar of advice and support long after James departed Lorraine. He provided valuable insights regarding the emperor's court and in advising James to marry to ensure dynastic continuity. He could also permit his courtiers to render their services to James. His initial interactions with James allowed him to improve relations with both France and Britain and to establish a good relationship with the man whom he believed would be the next king of Britain and Ireland. To that effect, he would attempt to set up a marriage between the Stuarts and Habsburgs. Leopold was required to take a different approach following the death of Louis XIV and the Hanoverian succession in 1715 and he openly courted relations with new regimes in Britain and France. Nevertheless, he continued to maintain relations with the Stuart exiles and offered what assistance he could while simultaneously strengthening his relationships with the emperor, France, and Britain. Support for James acted as a contingency plan in the event of a Stuart restoration in the unpredictable shifting political dynamic of the 1720s. Faced with indifference in his attempt to accede to the Quadruple Alliance, he was aware of the possibilities of using the Jacobite card once the emperor and Spain formed the Alliance of Vienna and secretly assisted James in dealing with the allies in 1727.

${ }^{100}$ Leopold to Jacquemin, 2 Aug. 1727 (ADMM, 3F 142, fo. 32); Stainville to Leopold, 21 Aug. 1727 (ADMM, 3F 85, fo. 120); Leopold to Jacquemin, 25 Aug. 1727 (ADMM, 3F 142, fo. 23); O'Rourke to James, 10 Sept. 1727 (ÖStA/HHStA, England Varia 8, O’Rourke to Jakob III, fo. 136).

${ }^{101}$ Leopold to James, 8 Aug. 1727 (ADMM, 3F 142, fo. 21).

102 James to Atterbury, 9 Aug. 1727, in Philip Stanhope, Lord Mahon, History of England from the Peace of Utrecht to the Peace of Aix-le-Chapelle (2nd edn, 2 vols., London, 1829), II, p. xxvi.

103 Leopold to Jacquemin, 14 Sept. 1727 (ADMM, 3F 152, fo. 15). 
As this article has highlighted, the relationship between Leopold and James illustrates the experiences of both small state princes and of exiled princes within the wider system of international relations. In Leopold's case, he could utilize his connections with James for his own strategic ends. The duke offers a prime example of a lesser power attempting to influence grander affairs of state and to enhance his own standing. But what of James? He has often been seen as a pawn of the great powers, to be used as leverage in their dealings with Britain. Given the good relations which existed between the two, it does not seem fair to suggest that the exiled James was merely Leopold's pawn. As James was never restored, he could not properly repay Leopold for his aid, but that is not to say that exiles were without influence. They can experience suffering but can display adaptability. They integrate into new societies and gain and wield political influence in their adopted homes. In the 1720s, as James was established in Rome, it was now Leopold who required the assistance of James in negotiating with the papacy. Additional research in both the archives in Nancy and in the Vatican Apostolic Archives may uncover further information on this aspect of James and Leopold's relationship and may reveal the extent to which the exiled James brought his influence to bear in Leopold's favour in Rome.

James's sudden arrival in Lorraine put Leopold in a difficult situation in 1727. The duke himself had been caught off guard and the responses from Versailles, Vienna, and London could not be ignored once it became known that James was in Lorraine. He could choose to openly support James and risk losing all that he had striven to gain for his house, or he could request James's departure and save face. He chose the second option and remained on good terms with the great powers. By the time of his death in 1729, he had obtained recognition for his use of the title Son Altesse Royale from both the emperor and France. He had also succeeded in establishing his eldest surviving son, Francis Stephen, as the primary suitor of Maria Theresa and as heir apparent to the emperor. To do so he cultivated relations through all possible avenues. This included both legitimate and non-legitimate polities. It was this latter connection that provided him greater room to manoeuvre in the ever-changing kaleidoscope that was early eighteenth-century international relations.

\footnotetext{
Acknowledgements. The author would like to thank the editors and the two anonymous reviewers, as well as Dr Jérémy Filet of Manchester Metropolitan University and Dr Anna Kalinowska of Tadeusz Manteuffel Institute of History, Polish Academy of Sciences, as well as Dr Richard Kirwan and Dr Alistair Malcolm of the University of Limerick for their generous time and constructive feedback on earlier drafts of this article. He also wishes to thank Dr Darren S. Layne of the Jacobite Database of 1745 for aiding him in obtaining copies of primary source material without which revisions would not have been possible.
}

Funding Statement. This research was completed with financial support kindly provided by the Richard Plaschka pre-doctoral Fellowship, ÖeAD, Vienna; the Rev. Liam Swords Foundation, Paris; and the Faculty of Arts, Humanities and Social Sciences, University of Limerick.

Cite this article: Griffin S (2022). Duke Leopold of Lorraine, Small State Diplomacy, and the Stuart Court in Exile, 1716-1729. The Historical Journal 65, 1244-1261. https://doi.org/10.1017/ S0018246X2100090X 